\title{
Instrumental Teacher Education in Kosovo: Competences, Roles and Contemporary Standardized Curricula
}

\author{
Fatbardh Gashi \\ University "Haxhi Zeka"-Faculty of Arts, Peja, Kosovo \\ fatbardh.gashi@unhz.eu
}

\section{Doi:10.5901/ajis.2015.v4n2s1p80}

\begin{abstract}
This research paper is focused on the instrumental teacher education and training in higher education in Kosovo. It investigates the competences, roles and contemporary standardized curricula that should be adopted and applied in the instrumental teaching program in Kosovo higher music institutions. The many various pedagogical and teaching programs that are offered in the two departments of Music of the public universities in Kosovo are based on a curriculum framework that has been used for many years undergoing minor changes. Therefore, instrumental teachers should firstly consider on their roles and competences that are a core issue towards building bridges for successfully accomplished programs. Except the lack of national collaboration, instrumental teachers have not been integrated in training programs that urge international cooperation as well. The key to curriculum development and its standardization towards European Curriculum Frameworks are projects and organizations that forge possibilities to be part of European education areas. This research explores widely the instrumental teaching process and praxis in the two higher music education institutions in Kosovo, respectively, the Faculties of Arts. And, by bringing an instrumental teaching framework, it calls for increased dialogues, interaction and collaboration at local and national levels. The paper also looks on different curriculum frameworks and training programs as well, by providing a comparison analysis, particularly, differences and similarities to Kosovo curricula for instrumental teacher education. Finally, the research shows that instrumental teacher education in Kosovo needs to be developed and embrace European standardized programs and praxis, since, Kosovo teaching system is in an ongoing process and is reconnected to the most recent developments in education, science and culture.
\end{abstract}

Keywords: instrumental education, instrumental teacher training, competences, roles, standardized curriculum, European instrumental teaching framework.

\section{Introduction}

Supporting instrumental teachers in their efforts to integrate standardized curriculum into their daily practice remains a challenge for the instrumental education community in Kosovo. An essential step in meeting this challenge involves formulating a theory to describe curriculum frameworks. Such a theory may then be used to inform and guide teachers in their efforts to integrate and apply instrumental teaching syllabuses successfully. Indeed, Trouche, L. (2004) introduced the notion of Instrumental Orchestration to describe teachers' need to support their students in the process of instrumental genesis. During the last years, other researchers have also handled and further developed the concept and matter of instrumental teaching. Yet, in order to have good instrumentalists and musicians, it is necessary to reexamine and possibly modify or expand the teaching curriculum accordingly towards European curriculum frameworks.

The aim of this study is to analyze the curricula of instrumental teaching by investigating widely on teachers' competences and roles and their appliance into the practice. The analysis is based on the syllabuses that have been used and begun integrating into the instrumental teaching practice in higher education in Kosovo. Regarding curricula, while the education system in Kosovo is in transition, when it comes to syllabuses and teaching framework, it may have a dose of ambiguity, especially choosing a common curriculum framework that meets the needs of each instrumental course. Additionally, instrumental teachers should consider on their competences and roles by improving the syllabuses' design to a convenient curricula. Besides this, a thorny issue is that how teachers could find congruence between students' motivations and their roles and competences representation towards practice and productive learning-teaching outcomes. But, the lack of collaboration between such teachers and professionals of international organizations and Music faculties, even though, the cooperation between the instrumental teachers at the national and local level is relatively poor. An appropriate opportunity for Kosovo instrumental teachers is the participation in international projects, exchange programs, workshops and conferences. In such ways, their capacities and competences are expanded and enhanced and then, could be transmitted to their students by compiling a common appropriate framework based on their students' capacities and potentials. 


\section{Theoretical Background}

These are some of the key components related to instrumental teaching and curriculum development based on international conferences and research on instrumental teaching and music education in higher education.

When we discuss about European standardized curriculum, the first that comes to mind is the Bologna Process that includes referring points and a unified framework for many European countries. As Prchel. M. (2008) mentioned in his presentation the main policy framework of the Bologna process that started in 1999 with the Bologna Declaration, in order to establish and develop the following issues:

1. The adoption of a system of easily readable and comparable degrees;

2. The adoption of a system essentially based on 2 cycles;

3. Establishment of a system of credits;

4. Promotion of mobility;

5. Promotion of European co-operation in quality assurance (QA);

6. Promotion of the European dimension in higher education;

The Bologna Declaration was extended with the following communiqués:

The Prague Communiqué (2001) focusing on:

7. Life Long Learning;

8. Higher Education institutions and students;

9. Promoting the attractiveness of the European Higher Education Area;

The Berlin Communiqué (2003) focusing on:

10. Doctoral studies and the synergy between the European Higher Education Area and the European Research Area;

The Bergen Communiqué (2005) focusing on:

11. Qualifications frameworks; (p. 10)

In addition, a study by MANA on Instrumental teaching and learning in context (as cited in Young, V. 2003, p.1) "proposed a framework for instrumental teaching drawing on two models-one for 'areas of study' and the other for 'teaching styles' to be used in instrumental teaching. "

According to Klemettinen, T. (2008), music teachers have different roles regarding teaching curriculum. Therefore, he presents the different roles of music teachers and the different kinds of music schools. There are many different roles of music teachers:

"Specialist Teacher": high skills and competences in a specific field of music;

$f$ "Multi talented teacher": many different kinds of skills and competences;

$f$ "Community teacher": different kinds of target groups;

$f$ "Developer teacher": music schools role in local music life;

$f$ "Networker teacher": cooperation and projects;

$f$ "Advocacy teacher": music schools role in society and culture politics;

The teaching curriculum in itself is a perplex set of objectives that intermingle the relationship between the instrumental teacher and the student. And, the roles of teacher in that case are prominent for student's success. If the roles are played successfully, so does the improvement of the student could be considered an achieved goal.

Considering that teaching methods, techniques and forms are a key concept for learning outcomes and the accomplishment of the syllabus, Witchell, J. (2008), presents the possible teaching forms, which are: one-to-one or in a large group.

\begin{tabular}{|ll|l|}
\hline 3. & Features & 4. \\
\hline 5. & One-to- One & 6. \\
\hline & & 16 \\
7. & & 17 \\
8. & Enjoyment: high expectations & 18. \\
9. & $f$ Aural development & 19 \\
10. & $f$ Performing & 20 \\
11. & $f$ Clear learning objectives & 2 \\
12. & $f$ Assessment for progression & 22 \\
13. & $f$ Learning based on individual needs & 23. \\
14. & $f$ Technical skills tailored to learner & 2 \\
15. & $f$ No 'discipline' problems & 25. \\
& & 26. \\
\hline
\end{tabular}

$\begin{array}{ll}\text { 4. } & \text { Of Learning } \\ \text { 6. } & \text { Large group } \\ \text { 16. } & f \\ \text { 17. } & \text { Enjoyment: high expectations } \\ \text { 18. } & f \text { Aural development } \\ \text { 19. } & f \text { Performing } \\ \text { 20. } & f \text { Clear learning objectives } \\ \text { 21. } & f \text { Assessment for progression } \\ \text { 22. } & f \text { More thought required to plan according } \\ \text { 23. } & \text { to needs and interests } \\ \text { 24. } & f \text { Less emphasis on individual technical } \\ \text { 25. } & \text { skills: more ensemble } \\ \text { 26. } & f \text { Social skills - crowd control }\end{array}$


Moreover, instrumental teachers and their roles have a direct impact to students' musical competencies and their abilities to perform music.

Another point is assignments and projects that instrumental students can be engaged in and related to that issue Buchanan, K. (2008) mentions the following areas, about students who study instrumental or vocal pedagogy in the UK:

- $f$ Projects led by players/composers/creative artists

- $f$ Cross arts projects including technology

- $f$ Schools (primary, secondary, special needs, specialist music schools/academies)

- $f$ Community e.g. festivals, young offenders

She also points out that in the end music graduates should stand out in performance and communication. They should have a flexible approach to new ideas and new ways of working and they should have an inquisitive attitude to collaboration and the ability to work across sector/age groups. Besides this, the students should also have leadership skills.

Finally, based on the teachers' answers, both faculties of Music included in this paper have not been part of any projects or progammes organized by Erasmus or Tempus. Regarding music teaching programmes, respectively, instrumental teaching, the most important in professional training for music teachers' collaboration and training opportunities are the projects organized by "Polifonia". Teaching is an ongoing process that always demands commitment to advance, and advancement comes when we direct our roles towards changes. Hence, changes could not happen without research and training.

\section{Participants and Data Collection}

In order to provide data for this research paper have been interviewed nine instrumental teachers and also as a second research instrument have been used the syllabuses of instrumental courses. Namely, were involved nine instrumental teachers, whereas, three other teachers refused to be part of the research. The names of the teachers that have been involved in this study are kept anonymous.

\section{Data Analysis}

The analysis of the data highlighted the predominance of same frameworks and curricula used in instrumental teaching in both departments of music in Kosovo. The answers from the interviews show that teachers are not enough aware of their roles and competences on designing their courses and syllabuses. Despite this, they are also partly informed about European frameworks that could enhance their syllabuses and instrumental teaching classes. On the other hand, the analysis of syllabuses shows a "uniformity sample" used by nearly all instrumental teachers in both faculties of Music. In both student and teacher's side, lacks the critical thinking and creativity.

Through the interviews have been given answers about many other points out the importance of contexts which are continuously changing. Instrumental teacher training deals with many different changing contexts such as: musical context, social context, educational context (e.g. group teaching or one-to-one teaching), national context (e.g. qualifications) as well as institutional context. Moreover, regarding the question "What are the key competences to be developed in relation to syllabuses?" The interviewed instrumental teachers answered that knowing such competences and developing them help educate properly the future instrumentalists.

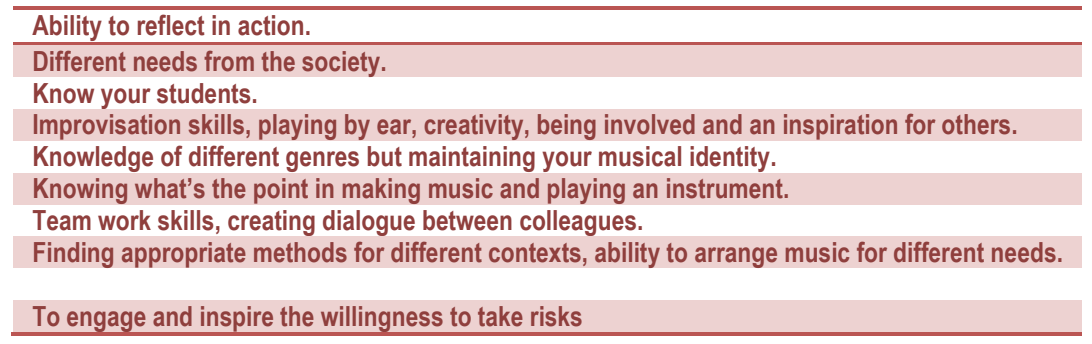

Beside the competences, teachers have been asked about their roles in teaching instrumental education, and how they apply such roles when deal with curriculum frameworks and syllabus design. Most of the interviewed teachers pointed 
out that instrumental teaching syllabuses need to be developed and enhanced and teachers should consider on their roles when it comes to that. Particularly, the question about the course objectives and contents, where, they stated that course objectives and frameworks are not reviewed and changed each semester and that is the issue to consider on in the future. Finally, the last point but not the least, the questions related to training programs that were included in the interview revealed that most of the instrumental teachers have been hardly included in such programs, workshops or conferences. And the need to be involved in training programs that examine instrumental teaching curricula and syllabus/course design programs are more than welcomed as well as necessary.

\section{Findings and Discussion}

Firstly, in both faculties, when it comes to course design on instrumental teaching, teachers' hardly share the advantages and disadvantages with their colleagues based on their experiences and mainly work on their own. The findings from the analyzed syllabuses prove that approximately all the twelve syllabuses are more than necessary to be enhanced and expanded. That should be started from the content of topics, methods, techniques and strategies that are addressed to student's achievement and improved performing skills. But, what would happen if we lack the collaboration of teachers and the correlation of syllabus content? Students' capacities and skills would be less improved and they would be not ready to take place in an international context. While the instrumental teaching is more oriented to practice, students should have motivation to practice individually as well as in small and large groups.

Secondly, the syllabuses and curriculum that are used in both departments of Music have not been changed for many years, namely, the same objectives, goals, assignments, projects and content have been used for different students. While, the course syllabus should be designed each semester based on students' needs and by setting objectives and exploring the overall content that should also be based on a common criteria. Students' achievement is relied on teachers 'roles and competences that should be known and previewed before they design the course and the syllabus as well.

Finally, there are many European standardized curriculums on instrumental teaching that could be used to improve the syllabuses by adjusting to students 'capacities and needs. Not all the students have the potentials to achieve the same goals in a course, therefore, should be considered on specific students skills, learning styles and strategies. This issue could be clarified by national and international instrumental teachers' cooperation.

\section{Conclusion and Recommendations}

To conclude, nevertheless, music education study programs have been provided since the establishment of the University of Prishtina, the instrumental teaching curriculum needs to be expanded and enhanced. University "Haxhi Zeka" is a new established higher education institution and the instrumental teaching is at the inception stage that should be expanded in programs and curricula towards standardized European instrumental teaching curriculum.

Hence, to plan a curriculum framework based on the standardized European curricula, collaboration with Erasmus Network is more than necessary and prospective, even though, Kosovo is not part of the EU yet.

The research results also show that it is very important to organize training programs for Kosovo instrumental teachers in order to enrich and advance curriculum knowledge, besides this, workshops and training programs are an opportunity to urge collaboration and transparency between instrumental teachers of Prishtina and Peja.

Based on the findings and results of this research, it is widely recommended to:

- To consider on curriculum frameworks and syllabuses in order to enhance the overall instrumental teaching process;

- To improve and analyze teachers' roles;

- To expand teachers' competences on choosing a framework and designing a course;

- To find congruence between faculty teachers and urge collaboration, not only organizing concerts but, primarily, considers the teaching frameworks;

- Teachers are free to choose and design the syllabuses that provide the opportunity to enhance the teaching frameworks;

- Even though, instrumental teaching is a compact subject, each syllabus should have specific objectives for each class/lecture and semester;

- Instrumental teachers should consider on achievable goals and objectives as well as convenient course contents; 
- Universities should offer opportunities and possibilities for the teachers to be part of international training programs as well as exchange programs;

- To integrate pedagogy into students' curriculum to have a more holistic education,particularly, on professional development;

Teachers 'roles and competences are the core concepts towards a proper curriculum. Hence, the roles should be known and played properly when it comes to syllabus design, and teachers are providers of such competences that could be develop and improved.

\section{Implications for Future Research}

The current study could be replicated in a variety of educational settings such as the pre-school instrumental teaching, the secondary school instrumental teaching, and especially to be expanded for the university instrumental teaching or any other educational setting where music education is administered. The data and findings could be adjusted to fit the observational needs of the researcher investigating younger or older students. Because of the conference criteria (10 pages), there have been shortly included the most important points of this research paper.

\section{References}

The Bologna Declaration (2008). AEC PJP Platform Lausanne.

Richard, C. (Fall 1963)"An Investigation of Musical Achievement among Vocal Students, Vocal-Instrumental Students, and Instrumental Students," Journal of Research in Music Education, Vol II.

Buchanan, K. (2008). (Director of Supporting Professional Studies, Royal Northern College of Music Manchester): Training music leaders and teachers in the United Kingdom.

Instrumental and vocal teacher education: European perspectives "Polifonia" working group for instrumental and vocal music teacher training, 2010;

Juntunen, M. L . (2014). Teacher educators' visions of pedagogical training within instrumental higher music education. A case in Finland . British Journal of Music Education, 31, pp 157-177;

Klemettinen, T. (2008) Different roles of music teachers. European Music School Union

Moreau, J. , \& Prchal, M. Changing Professional Roles: Presentation of competences and the student-oriented approach to curriculum development in relation to the presented contexts. Paper presented at the conference on the education of Instrumental and Vocal teachers in Europe - Changing professional roles and contexts, Helsinki, 28-29 March 2008.

Trouche, L. (2011) The notion of Instrumental Orchestration

Young,V. (2003) "Areas of Study and Teaching Strategies in Instrumental Teaching: a case study research project", Music Education Research.

Witchell. J . (2008) presented some of the changes in music services in England at the conference of the education of Instrumental and Vocal teachers in Europe - Changing professional roles and contexts Helsinki, 28-29 March 2008.

The Bologna Declaration, www.bologna-and-music.org.

https://www.hanze.nl/assets/kc-kunst--samenleving/lifelong-learning-inmusic/Documents/Public/aecconferencereporttheeducationofinstrumentalandvocalteachersineurope.pdf http://www.polifonia-tn.org/ 